\title{
Impacts of Monetary Policy on Vietnam Stock Price
}

\author{
Nguyen Trung Thanh ${ }^{1,2}$ a, Do Thi Linh ${ }^{3}$ \\ ${ }^{1}$ School of Economics, Shanghai University, Shanghai, China, 200444 \\ ${ }^{2}$ Faculty of Economics and Business Administration, Hatay Community college, Hanoi, VietNam \\ ${ }^{3}$ Faculty of Accounting and Finance, Hatay Community college, Hanoi, VietNam \\ anguyen_t_t@sina.com
}

Keywords: The monetary policy; Stock price; ARDL model

\begin{abstract}
Evaluating the impact of monetary policy on Vietnam stock market plays an important role for economists as well as stock investors. Stock price has not only gets impacts from the macroeconomic factors such as oil price, gold prices...but also be very sensitive to the changes in monetary policy. in each different markets, stock index are also different from each other. Hence, this paper is conducted to evaluate the impacts of monetary policy on Vietnam Stock Index (VNIDEX) in the period of 2006 till 2015. The author uses the model ARDL with time series data to evaluate the impact of monetary policy at considered lag level. The result shows that the monetary policy including interests, money supply and required reserve ratio has a negative impact on stock price in long term.
\end{abstract}

\section{Introduction}

Vietnam stock market was born in 2000 firstly in HCM city, but till 2005 the Stock center in Hanoi was established. Being a newborn trading center, but Vietnam Stock market has experienced the periods of both strong development and severe recession. From $2005-2008$ the stock price reached a record height as 1137.69 points on Mar 12th 2007, then fell sharply to 245.74 point on Feb 24th 2009. Since this period, the market grows slowly with the fluctuated level around 500 points.

Nowsaday, there are tens of billions of transactions on the Stock Exchange daily in Vietnam. Profits from stocks are the main income for many young peoples or the accumulated pension of the old (Maskay, 2007). The change (degradation) of the stock market will led to the turmoil in investors' lives because it directly relates to their main income. These changes are due to the impact of international market factors (Maskay, 2007) or the monetary policy (macroeconomic) of the state bank. Therefore; the study of impacts of policies especially monetary policy is considered as an important key which helps investors to make right decisions.

There have been many studies on fluctuation of the stock price and monetary policy. Most of them approved that stock indices react sensitively to changes of monetary policy (Azali, Zare. \& Habibullah, 2013). Stock Investors always keep their eyes on market' s changes in general and the monetary policy of the state bank in particular in order that they can make a right dicision which will bring benefit. Hence, stydying impacts of factors on stock price become a vital part which helps investors to make investing decision.

In Vietnam, nowsaday there are some studies on macroeconomics or the monetary policy (Ton \& Nguyen, 2015), however, there is not researches on the long-term or short-term impacts on the monetary on the stock price in detail. Therefore, this aim of this paper is asscessing the short term and long term impacts of the monetary policy on the stock price.

\section{Theoritical Overview and Researching Models}

Theoritical Overview. Monetary policy is a monetary measures implemented by the Centre Bank to make influence on economic activities, price stability, employment maximum and stability of the 
long-term interest rates (Okpara, 2010). In fact, many economists consider monetary policy as the most important macroeconomic policy (Maskay, 2007). Apart from the impact on inflation (within the allowed limit which is approved by the centre bank to control inflation and supervise bank system), the monetary policy also affects other aspects of the economy such as real GDP , unemployment and exchange rates, the stock market.

The theory of "efficient market" by Fama (1970) has set an extremely important theoritical basis for policy makers as well as stock investors. Accordingly, the policy makers can freely implement the national macro-economic policies without fearing that this policy will change the nature of the stock market because they only affect the stock price index. Since then there have been many researchers focusing on the impact of these monetary policies on changes in the stock index.

Monetary poliies can be conducted in many different tools such as rate policy, interest rates, money supply or the required reserve. The policy of interest rates gets the most atractions from researchers to assess the impact on the stock market. Studies have shown that interest has a opposite impact on the stock price (Ali, 2014; Dufour \& Tessier, 2006; Okpara, 2010; Fischbacher, 2012; Zare \& et al, 2013; Gali \& GAMBETTI, 2013). Standing at the second rank, exchange rate policy also gets careness from investors because they can evaluate the market change over the exchange rate policies of central banks (Maskay, 2007; Jamil \& Ulla, 2013; Adjasi \& et al, 2008). Some studies also examined the impact of money supply on the stock price (Homa \& Jaffe, 1971; Hamburger \& Chochin, 1972; Maskay, 2007; Nofeldt, 2014), it showed a positive relationship between the money supply and US stock market, typically the S \& P500 Index.

Besides three key factors, the central bank also uses a number of other tools in their operations as required reserve ratio for banks (Teja et al, 2013) and open market operations. However, for newborn financial markets like Vietnam, the application of the open market is not effective when the transaction is not entirely through banks. Therefore; open market operation seems not to affect to adjust the monetary policy as well as the stock market.

Researching Models. In this research, the author uses the time series data to evaluate the immediate impacts and influctuation at lag period. To solve the researhing aim, the author refer the previous studies and launch researching model with variables as below:

Tabel 1. Aspect and reference model.

\begin{tabular}{ccc}
\hline Variable name & Aspect & Authors \\
\hline Interest rate & - & Ali, 2014; Dufour \& Tessier, 2006; Okpara, 2010; Fischbacher, 2012; Zare \& et al, \\
Exchang rate & $-/+$ & 2013; Gali \& Gambetti, 2013 \\
Money Supply & + & Maskay, 2007; Jamil \& Ulla, 2013; Adjasi \& et al, 2008 \\
$\begin{array}{c}\text { Required reserve } \\
\text { ratio }\end{array}$ & - & Maskay, 2007; Nofeldt, 2014 \\
\end{tabular}

With interest rate, exchange rate, money supply and required reserve ratio are chosen as independent variables in the below model:

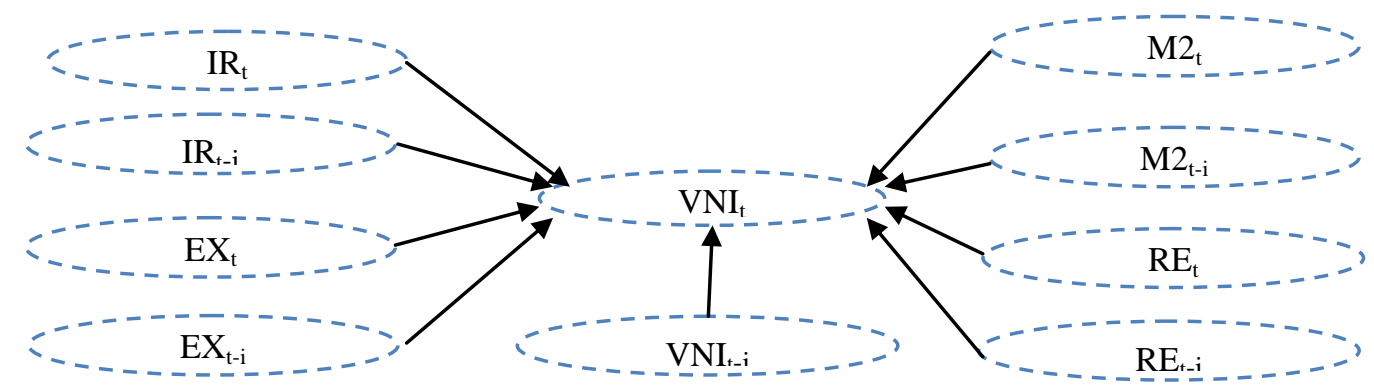

Figure 1. Researching Model 
In Which:

Dependent variables: VNI is VNINDEX price at time " $\mathrm{t}$ "

$\mathrm{VNI}_{\mathrm{t}-\mathrm{i}}$ is VNINDEX price at lag $\mathrm{i}$

Independent variables: $\quad \mathrm{IR}_{\mathrm{t}}$ : lending interest rates.

$\mathrm{EX}_{\mathrm{t}}$ : USD exchange rate.

$\mathrm{M} 2 \mathrm{t}$ : money supply.

$\mathrm{RE}_{\mathrm{t}}$ : required reseve ratio.

The Variables $\mathrm{IR}_{\mathrm{t}-\mathrm{i}} ; \mathrm{E}_{\mathrm{t}-\mathrm{i}} ; \mathrm{M} 2_{\mathrm{t}-\mathrm{i}}$ and $\mathrm{RE}_{\mathrm{t}-\mathrm{i}}$ are values at lag $\mathrm{i}$.

Method of Analysing. To evaluate the impact of the monetary policy on the stock price, the time series data is used on ARDL model to study.

For time series data, to ensure sustainable model before performing model ARDL, researchers used the data source without unit roots (stable data chain). The input data without unit roots will avoid fake regression case (Gurajati, 2003; Ramanathan, 2002).

In this study, in order to asscess impacts of the monetary policy on the Vietnam stock market in 2006-2015, the author also uses ARDL model to estimate monetary policy at lag level.

$\mathrm{Yt}=\alpha_{0}+\alpha_{1} * \mathrm{Y}_{\mathrm{t}-1}+\alpha_{2} * \mathrm{Y}_{\mathrm{t}-2}+\ldots+\alpha \mathrm{n}^{*} \mathrm{Y}_{\mathrm{t}-1}+\beta_{0} * \mathrm{Xi}_{\mathrm{t}}+\beta_{1} * \mathrm{Xi}_{\mathrm{t}-1}+\ldots+\beta_{\mathrm{n}} * \mathrm{Xi}_{\mathrm{t}-\mathrm{n}}+\mathrm{E}_{\mathrm{t}}+\mathrm{ut}$

In which: $Y t$ and $X t$ are variables without unit root; $u t$ is residual

$\mathrm{Y}_{\mathrm{t}-\mathrm{n}}$ and $\mathrm{X}_{\mathrm{t}-\mathrm{n}}$ are variables without unit root at lag levels.

Et is long-term impact of variables with unit root of $\mathrm{X}^{\mathrm{t}}$

Time series Data without unit roots is a series with constant mean, variance, covariance at every time (Gurajati, 2003). To test unit roots of time series data, the author use ADF (Gurajati, 2003).

Optimal lag is shown with variables are modeled through the lag variables and the other variables at the same lag level. The determination of the optimal latency is based on selected indicators (Hansen, 2013), these indicators are supported in EViews software.

To ensure a sustainable model, the regression equation needs to satisfy the conditions of redundant variables test (guarantee that models do not contain redundant variables - do not influence on the stock price); heteroscedasticity, autocorrelation.test.

\section{Researching Results}

Some Figures on the Monetary Policy and Stock Prices. Statistics describing the input data: In the period 2006 - 2013 the stock index reached 543.28 points at average; in which the maximum value reached 1137.69 points, the lowest value was 245.74 points. Lending rates was $12 \%$ per year at average, there was a period up to $20: 25 \%$ per year in 7/2008. Dollar exchange rate fluctuates around 18,789 VND / USD; consumer price index reached 107.67 at average; the money supply M2 monthly reached $2.51 \mathrm{E}+15$ at average and required reserve ratio was $4.16 \%$ in both periods (Table 2).

Table 2. The period 2006-2013

\begin{tabular}{ccccccc}
\hline & VNI & IR & EX & CPI & M2 & RE \\
\hline Mean & 543.28 & 12.00 & 18789.41 & 107.67 & $2.51 \mathrm{E}+15$ & 4.16 \\
Maximum & 1137.69 & 20.25 & 21673 & 145.10 & $5.34 \mathrm{E}+15$ & 11 \\
Minimum & 245.74 & 7.23 & 15914 & 62.48 & $6.76 \mathrm{E}+14$ & 3 \\
Observations & & & & 117 & & \\
\hline
\end{tabular}

Unit Root Test. To assess the impact of monetary policy on stock prices, the input variables needs to be ensured with data reliability in order to avoid the fake regression, data needs tobe without unit roots (Gujarati, 2003). The test results were obtained as follows: 
Table 3. Testing result for value without unit roots of data series

\begin{tabular}{|c|c|c|c|c|c|}
\hline \multirow{2}{*}{ Variables' name } & \multirow{2}{*}{ Test result ADF } & \multicolumn{3}{|c|}{ Statistical Value at the levels of significance. } & \multirow{2}{*}{ Prob } \\
\hline & & $1 \%$ & $5 \%$ & $10 \%$ & \\
\hline LVNI & -2.387 & -3.489 & -2.887 & -2.580 & 0.148 \\
\hline IR & -2.680 & -3.490 & -2.887 & -2.581 & 0.081 \\
\hline LEX & -0.515 & -3.489 & -2.887 & -2.580 & 0.883 \\
\hline LM2 & -2.373 & -3.489 & -2.887 & -2.580 & 0.152 \\
\hline $\mathrm{RE}$ & -3.388 & -4.067 & -3.462 & -3.157 & 0.060 \\
\hline \multicolumn{6}{|c|}{ THE FIRST DIFFERENCE } \\
\hline DLVNI & -8.254 & -4.041 & -3.450 & -3.150 & 0.000 \\
\hline DIR & -6.965 & -4.041 & -3.450 & -3.150 & 0.000 \\
\hline DLEX & -8.565 & -4.041 & -3.450 & -3.150 & 0.000 \\
\hline DLM2 & -9.299 & -4.041 & -3.450 & -3.150 & 0.000 \\
\hline DRE & -4.397 & -4.070 & -3.464 & -3.158 & 0.004 \\
\hline
\end{tabular}

Results showed that the variables do not stop at the level of significance of $1 \%, 5 \%$ and $10 \%$ so that the author uses the 1st difference and re-tests then finds out that 1st difference variables are satisfied for conditions of not having unit roots. Therefore; variables are put into the regression analysis at the first difference in the following steps.

Determining the Optimal Lag. In the economic study with time series data, factors not only have an immediate impact but also influence at late stages. To determine the optimal lag and to underestimate the influence of monetary policy on stock price indices correctly, authors used statistical indicators to determine appropriate lag level. Results from the data analysis for the period 2006 - 2015 are shown as follows (Table 4):

Table 4. The result for determining optimal lag

\begin{tabular}{ccccccc}
\hline Lag & LogL & LR & FPE & AIC & SC & HQ \\
\hline 0 & 96.27573 & NA* & 0.007703 & -2.02835 & $-1.889471^{*}$ & -1.97235 \\
1 & 97.98739 & 3.195099 & $0.007583^{*}$ & $-2.044164^{*}$ & -1.87751 & $-1.976959^{*}$ \\
2 & 98.23699 & 0.460385 & 0.007711 & -2.02749 & -1.833059 & -1.94908 \\
3 & 98.58347 & 0.631352 & 0.007825 & -2.01297 & -1.790761 & -1.92336 \\
4 & 98.90625 & 0.581014 & 0.007946 & -1.99792 & -1.747936 & -1.89711 \\
5 & 99.36337 & 0.812646 & 0.008044 & -1.98585 & -1.708096 & -1.87385 \\
6 & 100.588 & 2.149956 & 0.008007 & -1.99085 & -1.685313 & -1.86764 \\
7 & 100.6321 & 0.076398 & 0.008181 & -1.9696 & -1.636294 & -1.83519 \\
8 & 100.6887 & 0.09681 & 0.008358 & -1.94864 & -1.587554 & -1.80303 \\
\hline
\end{tabular}

Results showed that the study data sources affect each other in two stages (the impact of monetary policy on stock index immediately in that month and after one month). Thus, the authors choose lag 1 to establish a research model.

Testing for unit root. To determine the long-term relationsip between the monetary policy and the stock price, the author implemented testing for unit root.

Table 5. Testing unit root

\begin{tabular}{cccc}
\hline $\begin{array}{c}\text { Hypothesized } \\
\text { No. of CE(s) }\end{array}$ & Eigenvalue & Trace Statistic & Prob.** \\
\hline None $*$ & 0.560 & 149.452 & 0.000 \\
At most $1 *$ & 0.342 & 76.300 & 0.000 \\
At most $2 *$ & 0.283 & 39.111 & 0.003 \\
At most 3 & 0.089 & 9.558 & 0.316 \\
At most 4 & 0.014 & 1.292 & 0.256 \\
\hline
\end{tabular}


The results showed two long-term relationships between monetary policy and stock price. Therefore, by using the regressions ARDL, the author evaluates this long-term relationship in detail.

Regression Results. Since the studying objective is assessing the one-way impact of monetary policy on the stock price so, the author focuses on regression analysis without considering the cause and effect of the relationship between variables (Granger test). Firstly the authors will present a model studying the factors that impact on the stock price, then the variable with p-value bigger than 0.05 will be deleted from the model. Final results was obtained as belows:

To make sure the reability of the estimating model, the authors tested the violation of the hypothesis of regression estimates. The results showed that the model (1) does not meet Heteroscedasticity, Autocorrelation and Multicollinearity (Table 6). It shows credibility of the conclusions from the estimating model.

Table 6. Results of estimating factors' impact on stock price

\begin{tabular}{cccc}
\hline & DLVNI & S.E & Prob \\
C & $\beta$ & 0.768 & 0.006 \\
IR(-1) & 2.095 & 0.002 & 0.003 \\
LM2(-1) & -0.007 & 0.021 & 0.009 \\
RE(-1) & -0.055 & 0.005 & 0.003 \\
R2 & -0.016 & $11.11 \%$ & \\
Prob(F-s) & & 0.000 & \\
Heteroscedasticity test & 0.842 & 1.488 \\
Autocorrelation test & & p-value $>0.05$ & 2.159 \\
Multicollinearity test & IR(-1) & 1.862 \\
\hline
\end{tabular}

Results showed that monetary policy has the opposite effect on Vietnam stock price through three policy instruments: interest rates, money supply and required reserve ratio. However, the effects will have long-term impacts, but in the short-term, monetary policy seems to have no meaning in making the stock price change.

Discussion. Research results show that the macroeconomic policies (interest rate, money supply and required reserve ratio) have long-term impacts on the stock price. At the same time, the monetary policy limits stock price (oppositte impact on the stock price). The factor of exchange rate seems to be no meaning in changing stock market.

Interest rates have the opposite effect on the stock price. It shows that tightening the monetary (increasing interest rates) would make the stock market decrease. In the case of high inflation, state banks have tightened the monetary policy by raising interest rates, which in the short term will not affect the stock market, but in the long term it will have negative affect to businesses, especially companies that use large amounts of bank loans for their business operations. The research results of interest rate is compatible with previous studies of Ali, 2014; Dufour \& Tessier, 2006; Okpara, 2010; Fischbacher, 2012; Zare \& et al, 2013; Gali \& GAMBETTI, 2013.

The policy of required reserve ratio also has the opposite effect on the stock price. Increasing the ratio of required reserve in banks limited the amount exchanged between banks and outside individuals, business. In the short time, companies can invest or make liquidity by external borrowings. However, in the longer term, increasing required reserve ratio will causes many difficulties for enterprises' business activities.

Monetary supply policy has the opposite effect on the stock price in the long term. Result of the study has some differences with the study of Maskay, 2007; Nofeldt, 2014. This result is inconsistent with the theory of efficient markets, which indicates that current stock prices contain all available information (Menike, 2006). This result is similar to the study of Sprinkel (1964) and Homa \& Jafee (1971). In spite of large money supply, the implementation of projects as well as expansion of business activities to reach these loans are limited. The stagnant ammount in banks leads to economy 
degradation and falling stock price. In the contex of the economic crisis from 2008 till now, the economy has not really got recoveration so the theory of efficient market theory by Fama is no longer correct.

\section{References}

[1] Ali, H. (2014), Impact of Interest Rate on Stock Market; Evidence from Pakistani Market, Journal of Business and Management, 16(1), 64-6

[2] Adjasi, C., Harvey., S.K., \& Agyapong. (2008), Effect of Exchange Rate Volatility on the Ghana Stock Exchange, African Journal of Accounting, Economics, Finance and Banking Research, 3(3), 28-47

[3] Dufour, J.M., \& Tessier,D. (2006), Short-Run and Long-Run Causality between Monetary Policy Variables and Stock Prices, Bank of Canada Working paper

[4] Fama, E.F. (1970), Efficient Capital Markets: A Review of Theory and Empirical Work, The Journal of Finance, 25(2), 383-417

[5] Fischbacher, U., Hen, T., \& Zeisberger, S. (2012), The impact of monetary policy on stock market bubbles and trading behavior: evidence from the lab,

[6] Gali, J., \& Gambetti, L. (2013, 2014, 2015), The Effects of Monetary Policy on Stock Market Bubbles Some Evidence, NBER WORKING PAPER SERIES,

[7] Gurajati, D.N. (2003), Basic Econometrics, McGraw Hill.

[8] Hansen, B.E. (2014), Econometrics, University of Wisconsin.

[9] Homa, K.E., \& Jafee, D.M. (1971), The Supply of Money and Common Stock Prices, The Journal of Finance, 25(5), 1045-1066

[10] Jamil, M., \& Ulla,N. (2013), Impact of Foreign Exchange rate on stock prices, Journal of Business and Management, 7(3), 45-51

[11] Maskay, B. (2007), Analyzing the Effect of Change in Money Supply on Stock Prices, The Park Place Economist, 15, 72-97

[12] Menike, L.M.C.S. (2006), The Effect of Macroeconomic Variables on Stock Prices in Emerging Sri Lankan Stock Market, Sabaragamuwa University Journal, 6(1), 50-67

[13] Nofeldt, O. (2014), The effects of Monetary Policy on Stock Market Returns, UMEA University, $1-34$

[14] Ton, H.T.H., \& Nguyen, V.N. (2015), The Impact of The International Price Index on Vietnam Stock Market, International Conference on Emerging Challenges: Managing to Success, 1, $132-138$

[15] Okpara, G.C. (2010), Monetary Policy and Stock Market Returns: Evidence from Nigeria, Journal Economic, 1(1), 13-21

[16] Ramanathan, R. (2002), Introductory Econometrics with Applications, Harcourt College Publishers.

[17] Sprinkel, B.W. (1964), Money and Stock Prices. New York: Richard D. Irwin, Home wood, III.

[18] Teja, K.R., Tejaswi, M., Madhavi., \& Ujwala, G. (2013), Cash Reserve Ratio impact on Stock Market (India) in Long run, International Journal of Marketing, Financial Services \& Management Research, 2(8), 85-93 
[19]Zare, R., Azali, M., \& Habibullah, M.S. (2013), Monetary Policy and Stock Market Volatility in the ASEAN5: Asymmetries over Bull and Bear Markets, International Conference on Economics and Business Research 2013, 18-27 